\title{
Port Maintenance Handbook
}


Downloaded by [] on [26/04/23]. Copyright (C) ICE Publishing, all rights reserved. 


\section{Port Maintenance Handbook}

\section{George Steele}


Published by ICE Publishing, One Great George Street, Westminster, London SW1P 3AA

Full details of ICE Publishing representatives and distributors can be found at: www.icebookshop.com/bookshop_contact.asp

\section{Other titles by ICE Publishing:}

Port Designer's Handbook, Fourth edition

Carl A. Thoresen. ISBN 978-0-7277-6307-5

Piers, Jetties and Related Structures Exposed to Waves - Guidelines for Hydraulic Loading

Kirsty McConnell, William Allsop and lan Cruickshank.

ISBN 978-0-7277-3265-1

Design of Vertical Gravity Sea and Quay Walls

Marisa Ackhurst. ISBN 978-0-7277-6361-7

www.icebookshop.com

A catalogue record for this book is available from the British Library

ISBN 978-0-7277-6413-3

(C) Thomas Telford 2021

ICE Publishing is a division of Thomas Telford Ltd, a wholly-owned subsidiary of the Institution of Civil Engineers (ICE).

All rights, including translation, reserved. Except as permitted by the Copyright, Designs and Patents Act 1988, no part of this publication may be reproduced, stored in a retrieval system or transmitted in any form or by any means, electronic, mechanical, photocopying or otherwise, without the prior written permission of the Publisher, ICE Publishing, One Great George Street, Westminster, London SW1P 3AA.

This book is published on the understanding that the author is solely responsible for the statements made and opinions expressed in it and that its publication does not necessarily imply that such statements and/or opinions are or reflect the views or opinions of the publishers. While every effort has been made to ensure that the statements made and the opinions expressed in this publication provide a safe and accurate guide, no liability or responsibility can be accepted in this respect by the author or publishers.

While every reasonable effort has been undertaken by the author and the publisher to acknowledge copyright on material reproduced, if there has been an oversight please contact the publisher and we will endeavour to correct this upon a reprint.

Cover photo: EUROGATE container terminal in the Port of Hamburg at sunset, Waltershof, Hamburg, Germany. ImageBROKER/Alamy Stock Photo

Commissioning Editor: James Hobbs

Development Editor: Melanie Bell

Production Editor: Madhubanti Bhattacharyya

Marketing Specialist: April Nagy

Typeset by Academic + Technical, Bristol

Index created by Matthew Gale

Printed and bound in Great Britain by Bell and Bain, Glasgow 
'Scientists explore what is - engineers create what has never been.'

Isambard Kingdom Brunel

This book is dedicated to my wife Mary-Anne,

whose inspiration and belief in me was the drive behind the writing of the book.

George R Steele 
Downloaded by [] on [26/04/23]. Copyright (C) ICE Publishing, all rights reserved. 
01

Purpose of this book

02

2.2. Quays, jetties and dolphins 22

2.3. Fenders 34

2.4. Concrete decks and piles 38

2.5. Steel piles 51

2.6. Inspections and maintenance procedures 55

2.7. Breakwaters 63

2.8. Life-cycle management 65

2.9. Maintenance dredging 71

$\begin{array}{ll}\text { Further reading } & 87\end{array}$

03

Maintenance department $\quad 89$

3.1. General 89

3.2. Quay, jetty and pavement loadings 89

3.3. Buildings 90

3.4. Impact of ship design 90

3.5. Cargo handling equipment 91

3.6. Natural wear and tear 91

3.7. Maintenance staff 91

3.8. Design optimisation to reduce future maintenance costs 94

3.9. Maintenance management 96

3.10. Maintenance strategy 96

Further reading $\quad 98$

$04 \ldots \ldots \ldots \ldots \ldots \ldots \ldots \ldots$ Buildings $\quad 99$

4.1. General 99

4.2. Cleaning 99

4.3. Roofing 99

4.4. General running repairs 105

4.5. Utilities 106

$\begin{array}{ll}\text { Further reading } & 107\end{array}$

$05 \ldots \ldots \ldots \ldots \ldots \ldots \ldots \ldots$ Health and safety 109

5.1. Regulatory framework and guidance 109

5.2. Risk assessments 109

5.3. Hot work permits 110

5.4. Lifting and slinging (LOLER) 110

5.5. Provision and Use of Work Equipment Regulations
1998 (PUWER)

5.6. Manual handling 116

5.7. Working in confined spaces 118

5.8. Working at height 119 
5.9. Bulk solids and bulk liquids terminals

5.10. Container terminals

5.11. Passenger terminals

5.12. Roll-on/roll-off (ro-ro) terminals

5.13. Warehouses and transit sheds

5.14. Port railways

124

Further reading

06

Roll-on/roll-off ramps

127

6.1. General

6.2. Types of ro-ro ramps 127

Further reading

07

Mechanical and electrical

133

7.1. General

133

7.2. Cranes

133

7.3. Straddle carriers

146

7.4. Forklifts

149

7.5. Tractor units

151

7.6. Trailers

152

7.7. Automated guided vehicles

153

7.8. Electrical supplies

154

7.9. Port lighting

156

7.10. Telecommunications

7.11. Passenger access gangways

7.12. Protective coatings

Further reading

8.1. General 167

8.2. Lock chambers 167

8.3. Sluices 169

8.4. Lock gates 171

8.5. Lock gate operating machinery 178

8.6. Maintenance 180

8.7. When things go catastrophically wrong 192

8.8. The Panama Canal, Panama 199

8.9. The Welland Canal, US 201

Further reading 202

$\begin{array}{ll}\text { Index } & 203\end{array}$

viii 


\section{About the author}

\section{George Steele}

After gaining a BSc (Hons) in Civil Engineering at Strathclyde University, Glasgow, George Steele started his career in 1970 with Belfast Harbour Commissioners. He moved to the Port of Felixstowe in 1983 and was appointed Head of Engineering in 1991 and further promoted to General Manager - Engineering in 1998. In 2000 he joined ABP Port of Southampton as Port Engineer. In 1974 he became a Chartered Member of the Institution of Civil Engineers and in 1993 he was elected a Fellow. In 2004 George set up his own consultancy business, George Steele Consultancy Ltd, and has since been engaged in numerous projects worldwide.

With over 50 years of experience, George is an extremely experienced and highly qualified engineer.

Eminently respected in the port and maritime industry, he was called as an expert witness at the Old Bailey in London on the Port of Ramsgate roll-on/roll-off passenger walkway inquiry.

George brings his practical experience of design, construction and maintenance under working port conditions within the public and private sectors. With 34 years' experience as a Client Engineer, and over 16 years running his own port consultancy business, he is thoroughly conversant with the requirements of both UK and international port infrastructure and equipment. As an in-house Client Engineer he has first-hand knowledge of the requirements of port operators, both from capital investment and ongoing maintenance aspects. His expertise encompasses the whole of port engineering, from railways, roads, drainage, buildings, dredging, container, bulk, roll-on/roll-off and cruise terminals.

While Port Engineer at the Port of Southampton, UK, he was responsible for the day-to-day maintenance and development of the port's infrastructure, including container, bulk and cruise terminals.

As General Manager - Engineering at the Hutchison Ports Ltd, Port of Felixstowe, the UK's largest container port, he was responsible for all civil, mechanical and electrical maintenance and dredging requirements, as well as the design, construction and equipment procurement for the phased construction of the UK's largest Trinity Container Terminal. He was also responsible for the construction of Phase 1 of the Hutchison hub port at Freeport, Grand Bahamas.

He has been a member of many technical committees for both the International Navigation Association (PIANC) and the Institution of Civil Engineers (ICE), including:

- Chairman, PIANC Working Group 135: Design of Small and Medium Size Container Terminals, 2009-2014

- Vice Chairman, PIANC Working Group 42: Life Cycle Management of Port Structures - Guide to Implementation, 2004-2007 
Member, PIANC Working Group 17: Maintenance of Port Structures in the Marine Environment, 1987-1991

- Vice Chairman of ICE Maritime Board, 2006-2009

- Chairman of ICE South Maritime Group, 2007-2012

- Member of the ICE Maritime Journal Editorial Panel, 2006-2010.

He has also been an active participant in international conferences and presented papers on a range of topics, including astronomical low-water corrosion in steel piles, container terminal pavements, privatisation of British ports and the consents process in the maritime environment.

In addition, he contributed to a number of chapters in the Port Designer's Handbook by Carl A. Thoresen.

His international experience includes involvement in the following countries outside of the UK:

Abu Dhabi, Angola, Australia, Bahrain, Belgium, Brazil, Croatia, Democratic Republic of Congo, Denmark, Dubai, Finland, France, Grand Bahamas, Haiti, Hong Kong, India, Italy, Japan, Libya, Morocco, Netherlands, Nigeria, Pakistan, Panama, Republic of Ireland, Russia, Sharjah, South Africa, Spain, Tanzania, Turkey, USA. 


\section{Acknowledgements Ray Howells}

Ray Howells is a Fellow of the Institution of Mechanical

Engineers and from 1989 until his retirement in 2004 was Chief Engineer of the Manchester Ship Canal Company, UK.

Ray's experience covers all aspects of mechanical, electrical and civil engineering maintenance, including canal structures, cargo handling plant, container and floating cranes, leaf and caisson lock gates and fixed and moving bridges.

He represented the company on the British Ports Association Engineering Committee and was a director of the Mersey Basin Campaign. As a co-author, he won the Institution of Civil Engineers, UK, Sir William Halcrow prize for a paper entitled 'River Mersey Diversion and New Air Regulated Syphon'.

I am grateful and indebted for his extensive input into Chapter 8: Locks in this book.

\section{Gerhard Mickeleit}

I am indebted to Gerhard Mickeleit, who has provided me with a considerable amount of material which I have incorporated into Chapter 7. Gerhard formerly worked for Konecranes, one of the leading manufacturers of port equipment in the world, and is now owner of his consultancy business, SERVICE4PORTCRANESINTERNATIONAL, based in Germany.

\section{Manchester Ship Canal Company}

I am grateful to the Manchester Ship Canal Company for permitting access to their records and use of photographs, which have been used in Chapter 8 .

\section{Dubai Ports World - Antwerp Container Terminal}

I am grateful to Dubai Ports World - Antwerp Container Terminal, and their professional phototographer, Frank Bahnmuller, for the use of container handling equipment photographs.

\section{Konecranes}

Thanks to Konecranes, who kindly permitted Gerhard Mickeleit use of information and photographs.

\section{Samuel Gledhill}

A special thanks to my stepson Samuel Gledhill, a fully qualified architect, who using his CAD skills was able to turn rather basic sketches, provided by Ray Howells and myself, into presentable figures for insertion in the book.

\section{ICE Publishing}

Finally, thanks to ICE Publishing, the publishing division of the Institution of Civil Engineers, for agreeing to publish this book and for their help in preparing the final manuscript for printing. 
Downloaded by [] on [26/04/23]. Copyright (C) ICE Publishing, all rights reserved. 


\section{Glossary}

$\begin{array}{ll}\text { ACOP } & \text { Approved Code of Practice } \\ \text { AGV } & \text { automated guided vehicle } \\ \text { ALWC } & \text { accelerated low-water corrosion } \\ \text { ASC } & \text { automated stacking crane } \\ \text { b/c } & \text { base course asphalt } \\ \text { CBM } & \text { cement-bound material } \\ \text { CE } & \text { Council of Europe Approval } \\ \text { CMS } & \text { crane monitoring system } \\ \text { CP } & \text { cathodic protection } \\ \text { CPU } & \text { central processing unit } \\ \text { CSD } & \text { cutter suction dredger } \\ \text { CSM } & \text { chopped strand mat } \\ \text { CSU } & \text { continuous ship unloaders } \\ \text { dft } & \text { dry film thickness } \\ \text { DGPS } & \text { dredging ground positioning systems } \\ \text { DoC } & \text { Declaration of Conformity } \\ \text { ECH } & \text { empty container handler } \\ \text { EPDM } & \text { ethylene propylene diene monomer } \\ \text { E-REV } & \text { extended-range electric vehicle } \\ \text { EV } & \text { electric vehicle } \\ \text { FIDIC } & \text { Federation Internationale des Ingenieurs-Conseils } \\ \text { FLT } & \text { forklift truck } \\ \text { FRP } & \text { fibre-reinforced plastic } \\ \text { FWD } & \text { falling weight deflectometer } \\ \text { GPS } & \text { Global Positioning System } \\ \text { GRP } & \text { glass-reinforced plastic } \\ \text { HRA } & \text { hot-rolled asphalt } \\ \text { HRM } & \text { high-speed road monitor } \\ \text { HV } & \text { high voltage } \\ \text { HWMST } & \text { high-water mean spring tide } \\ \text { HWST } & \text { high-water spring tide } \\ \text { IAPH } & \text { International Association of Ports and Harbours } \\ \text { ICS } & \text { incident command system } \\ \text { ILO } & \text { International Labour Organization } \\ \text { ISGOTT } & \text { International Safety Guide for Oil Tankers and } \\ & \text { Terminals } \\ \text { kV } & \text { kilovolts } \\ \text { kVA } & \text { kilovolt amperes } \\ \text { LCM } & \text { life-cycle management } \\ \text { LED } & \text { light-emitting diode } \\ \text { LOLER } & \text { Lifting Operations and Lifting Equipment Regulations } \\ \text { LV } & \text { low voltage } \\ \text { MAFI } & \text { mobile loading platform (commonly known as MAFI) } \\ \text { MCRMA } & \text { Metal Cladding and Roofing Manufacturers } \\ \text { MEWP } & \text { Association } \\ \text { MHC } & \text { mobile-elevated working platform } \\ \text { MIC } & \text { microbiologically induced corrosion } \\ \text { MSD } & \text { micaceous iron oxide } \\ & \text { Manchester Ship Canal } \\ \text { musculoskeletal disorders }\end{array}$




$\begin{array}{ll}\text { MVA } & \text { megavolt amperes } \\ \text { MW } & \text { medium voltage } \\ \text { MWLST } & \text { mean-water low spring tide } \\ \text { NDT } & \text { non-destructive testing } \\ \text { NRT } & \text { net registered tonnes } \\ \text { PAG } & \text { passenger access gangway } \\ \text { PCB } & \text { polychlorinated biphenyl } \\ \text { PCB } & \text { printed circuit board } \\ \text { PHEV } & \text { plug-in hybrid electric vehicle } \\ \text { PIANC } & \text { Permanent International Association of Navigation } \\ & \text { Congresses } \\ \text { PLC } & \text { programmable logic controller } \\ \text { PM } & \text { preventative maintenance } \\ \text { PUWER } & \text { Provision and Use of Work Equipment Regulations } \\ \text { PVC } & \text { polyvinyl chloride } \\ \text { PVF } & \text { polyvinyl finish } \\ \text { RMGC } & \text { rail-mounted gantry crane } \\ \text { Ro-ro } & \text { roll-on/roll-off } \\ \text { ROV } & \text { remotely operated vehicle } \\ \text { RS } & \text { reach stacker } \\ \text { RTG } & \text { rubber-tyred gantry crane } \\ \text { SA } & \text { Swedish Pictorial Standard } \\ \text { SC } & \text { straddle carrier } \\ \text { ShC } & \text { shuttle carrier } \\ \text { SMA } & \text { stone mastic asphalt } \\ \text { SOLAS } & \text { International Convention for Safety of Life at Sea } \\ \text { Son-T } & \text { sodium lights } \\ \text { SRB } & \text { sulphate-reducing bacteria } \\ \text { STO-RO } & \text { roll-on/roll-off stowage vessel } \\ \text { SWL } & \text { safe working load } \\ \text { TSHD } & \text { trailing suction hopper dredger } \\ \text { VCS } & \text { visual condition surveys } \\ \text { w/c } & \text { wearing course asphalt } \\ \text { WID } & \text { water injection dredging } \\ \text { WLC } & \text { whole-life costing } \\ & \\ & \end{array}$

